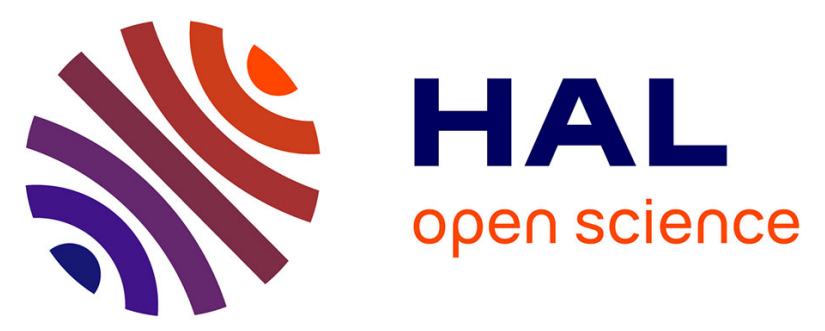

\title{
Convenient Grafting Through Approach for the Preparation of Stealth Polymeric Blood Pool Magnetic Resonance Imaging Contrast Agents
}

M. Grogna, R. Cloots, A. Luxen, Christine Jérôme, Catherine

Passirani-Malleret, Nolwenn Lautram, J.-F. Desreux, Christophe Detrembleur

\section{To cite this version:}

M. Grogna, R. Cloots, A. Luxen, Christine Jérôme, Catherine Passirani-Malleret, et al.. Convenient Grafting Through Approach for the Preparation of Stealth Polymeric Blood Pool Magnetic Resonance Imaging Contrast Agents. Journal of Polymer Science Part A: Polymer Chemistry, 2011, 49 (17), pp.3700-8. 10.1002/pola.24805 . hal-03171872

\section{HAL Id: hal-03171872 \\ https://univ-angers.hal.science/hal-03171872}

Submitted on 17 Mar 2021

HAL is a multi-disciplinary open access archive for the deposit and dissemination of scientific research documents, whether they are published or not. The documents may come from teaching and research institutions in France or abroad, or from public or private research centers.
L'archive ouverte pluridisciplinaire HAL, est destinée au dépôt et à la diffusion de documents scientifiques de niveau recherche, publiés ou non, émanant des établissements d'enseignement et de recherche français ou étrangers, des laboratoires publics ou privés. 


\title{
Convenient Grafting Through Approach for the Preparation of Stealth Polymeric Blood Pool Magnetic Resonance Imaging Contrast Agents
}

\author{
MATHURIN GROGNA, ${ }^{1}$ RUDI CLOOTS, ${ }^{2}$ ANDRÉ LUXEN, ${ }^{3}$ CHRISTINE JÉRÔME, ${ }^{1}$ CATHERINE PASSIRANI, ${ }^{4}$ \\ NOLWENN LAUTRAM, ${ }^{4}$ JEAN-F. DESREUX, ${ }^{5}$ CHRISTOPHE DETREMBLEUR $^{1}$ \\ ${ }^{1}$ Center for Education and Research on Macromolecules, University of Liège, B6 Sart-Tilman, Liège B-4000, Belgium \\ ${ }^{2}$ Laboratoire de chimie inorganique structurale, University of Liège, B6 Sart Tilman, Liège B-4000, Belgium \\ ${ }^{3}$ Cyclotron Research Centre, University of Liège, B6 Sart Tilman, Liège B-4000, Belgium \\ ${ }^{4}$ INSERM U 646, 10 Rue A Boquel, Angers 49000, France \\ ${ }^{5}$ Coordination and Radiochemistry, University of Liège, B6 Sart Tilman, Liège B-4000, Belgium
}

Received 15 April 2011; accepted 25 May 2011

DOI: $10.1002 /$ pola.24805

Published online 20 June 2011 in Wiley Online Library (wileyonlinelibrary.com).

\begin{abstract}
New hydrosoluble magnetic resonance imaging (MRI) macrocontrast agents are synthesized by reversible addition fragmentation chain transfer (RAFT) copolymerization of poly(ethylene oxide) methyl ether acrylate (PEOMA) with an acrylamide bearing a ligand for gadolinium, followed by the complexation of $\mathrm{Gd}^{3+}$. This convenient and simple grafting through approach leads to macrocontrast agents with a high relaxivity at high frequency that is imparted by the restricted tumbling of the $\mathrm{Gd}^{3+}$ complex caused by its attachment to the polymer backbone. Importantly a very low protein adsorption is also evidenced by the hemolytic
\end{abstract}

$\mathrm{CH} 50$ test. It is the result of the poly(ethylene oxide) (PEO) brush that efficiently hides the gadolinium complex and renders it stealth to the proteins of the immune system. Improved contrast and long blood circulating properties are thus expected for these macrocontrast agents. (c) 2011 Wiley Periodicals, Inc. J Polym Sci Part A: Polym Chem 49: 3700-3708, 2011

KEYWORDS: biological applications of polymers; functionalization of polymers; gadolinium complex; grafting through; MRI; reversible addition-fragmentation chain transfer (RAFT)
INTRODUCTION The search for macromolecular Gd(III) containing contrast agents $(\mathrm{CAs})^{1}$ has been an important issue in the past decade in the development of magnetic resonance imaging (MRI). CAs that increase the relaxation rate of water molecules and improve the contrast between tissues of interest, are now widely used in clinical settings but they suffer from a poor sensitivity. The quest for new agents that can be detected by MRI at much lower concentrations thus remains an active area of research.

The CAs presently clinically used comprise a Gd(III) ion chelated by a small organic molecule to reduce the toxicity associated with the free metal ion $^{2}$ but they are not optimized to generate maximum contrast. The effective molecular sensitivity of these agents may be improved by attaching multiple $\mathrm{Gd}^{3+}$ chelates to macromolecules ${ }^{1}$ or to various types of organic $^{3,4} /$ inorganic $^{5,6}$ nanoparticles. This approach enhances the molecular relaxivity of $\mathrm{Gd}^{3+}$ and also results in larger particles that exhibit a prolonged blood circulation that allows a better molecular targeting to tumors or other sites of interest. According to the SBM (Solomon-BloembergenMorgan) theory, these macromolecular systems provide an enhanced ability to catalyze solvent proton relaxation rates because of their longer tumbling rates. ${ }^{7,8}$ The relaxation effect then becomes a function of the water exchange and of the electronic correlation times, the latter being frequency dependent. This leads to a relaxation maximum between 20 and $100 \mathrm{MHz}$. Moreover, macromolecular systems increase the lifetime of CAs in the circulating blood by avoiding the extravasation typical of the small-sized Gd(III) complexes commonly used in MRI investigations. Blood lifetime and extravasation are indeed dependent on two main parameters: (1) complement system recognition and (2) kidney clearance. Recognition by the complement system can be strongly decreased by masking CAs by stealth poly(ethylene oxide) (PEO) chains ${ }^{9}$, whereas kidney clearance can be limited by the hydrodynamic diameter ${ }^{10}$ of CAs. As blood passes through the kidneys, where the glomerulus filters out solutes, waste products, and excess water. These bio-filters consist of a matrix of collagen-like moieties and glycoproteins that form pore size ranging from 4 to $14 \mathrm{~nm} .{ }^{10}$ Molecules with hydrodynamic diameter smaller than glomerular pores readily permeate and are removed from the body via urine. ${ }^{11}$ Fast renal clearance can thus be partially suppressed by grafting gadolinium complexes onto macromolecules with sufficiently high hydrodynamic volumes. The grafting of gadolinium chelates onto linear macromolecules is thus 


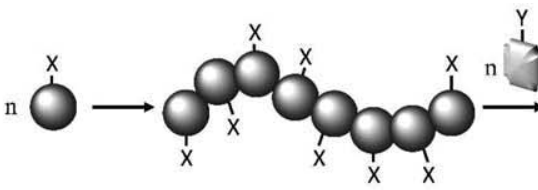

Grafting onto
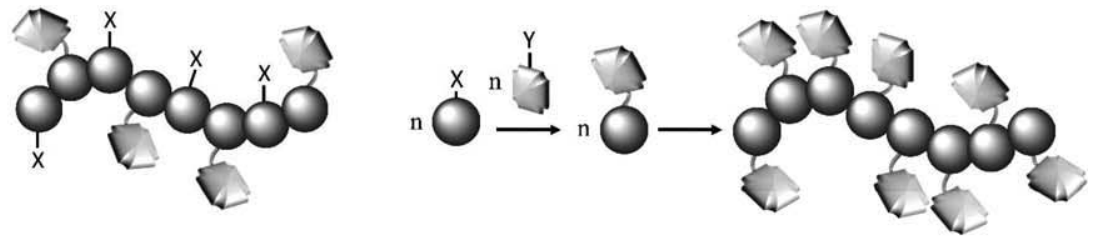

SCHEME 1 Comparison of "grafting onto" and "grafting through" methods used to modify polymers. ( $x$ and $y$ functions in the "grafting onto" strategy are mutually reactive.)

extensively investigated. Various strategies exist such as anchoring bis(anhydride) derivative of diethylenetriaminepentaacetic acid (DTPA) on amine functionalized macromolecules. (GdDTPA $)_{n}$-albumin, ${ }^{12}$ (GdDTPA $)_{n}$-polylysine ${ }^{13,14}$, and dendrimers $^{15,16}$ are typical examples. The main drawbacks encountered with these CAs are the difficulty to synthesize large amounts of bis(anhydride) derivative of DTPA and the occurrence of undesirable intra- and intermolecular crosslinking reactions. ${ }^{17}$ Macromolecular dendrimer CAs are very well-defined structures with a high relaxivity but purification is particularly difficult. ${ }^{15}$ The inverse strategy has also been used by grafting primary amine bearing chelates $[1,4,7,10$ tetraaza cyclododecane-1,4,7,10-tetraacetic acid (DOTA)] or DTPA onto polymers functionalized by the complementary reactive function such as activated esters ${ }^{18}$ or aldehyde functionalized micelles. ${ }^{19}$ GdDOTA was also grafted to poly (lysine)s (PLLs) through amidation by reacting free carboxylic acid functions of the metal chelate with primary amines of PLL. Grafting yields around 25\% were reported. ${ }^{20}$

Most of these works are based on "grafting to" methods, where the gadolinium chelate is anchored to a preformed macromolecule (Scheme 1). This multistep procedure requires to (i) functionalize the chelate, (ii) synthesize the macromolecule bearing the complementary function, and (iii) anchor the chelate to the polymer. Problems of low grafting yields, side reactions such as cross-linking and/or ill-defined final products may take place thus limiting the possibility of using these macrocontrast agents as effectively as needed.

In the following study we aim at developing a convenient, simple, and efficient method for the production of new welldefined stealth MRI CAs of high relaxivity. Our strategy is based on a "grafting through" method ${ }^{21}$ that allows preparing macrocontrast agents by the copolymerization of a chelate bearing a polymerizable function with a comonomer ensuring water solubility and stealthiness (Scheme 1).

\section{EXPERIMENTAL PROCEDURES}

\section{Materials}

$S$-1-Dodecyl- $S^{\prime}$ - $\left(\alpha, \alpha^{\prime}\right.$-dimethyl- $\alpha^{\prime \prime}$-acetic acid)trithiocarbonate (CTA) was synthesized according to the procedure described elsewhere. $^{22}$ Dichloromethane, methanol, ethyl acetate, triethylamine, acetonitrile, methyl bromoacetate, ethylenediamine, acryloyl chloride, poly(ethylene oxide) methyl ether acrylate (PEOMA), potassium carbonate, potassium hydrox- ide, ammonium chloride, sodium bicarbonate, heptane, gadolinium chloride, deuterated chloroform $\left(\mathrm{CDCl}_{3}\right)$ with tetramethylsilane (TMS) and sulfate magnesium were purchased from Sigma-Aldrich. The 1,4,7-tris(1,1-dimethylethyl) ester of 1,4,7,10-tetraazacyclododecane-1,4,7-triacetic acid ( $\left.\mathrm{DO}_{3} \mathrm{AtBu}\right)$ and DOTA were purchased from Chematech. Diethyl ether and dimethylformamide (DMF) were purchased from VWR. 2,2'-Azobis(2-methylpropionitrile) (AIBN) was purchased from Fluka. All products were used as received.

\section{Synthesis}

Synthesis of the $\mathrm{DO}_{3} \mathrm{~A}$ Chelate Functionalized by an Acrylamide Group $\left(\mathrm{DO}_{3} \mathrm{AtBuAM}\right)$

Synthesis of $\mathrm{DO}_{3} \mathrm{~A}$ Mono-methyl Tris-tert-butyl Ester, $\mathrm{DO}_{3} \mathrm{AtBu}-\mathrm{OMe}$, tert-Butyl 2,2',2'-(10-(2-Methoxy-2-oxoethyl)1,4,7,10-tetraazacyclododecane-1,4,7-triyl)triacetate. $\mathrm{DO}_{3} \mathrm{AtBu}$ ( $9.57 \mathrm{~g}, 18.6 \mathrm{mmol})$ was dissolved in $150 \mathrm{~mL}$ of acetonitrile. $\mathrm{K}_{2} \mathrm{CO}_{3} \quad(6 \mathrm{~g})$ and $2.12 \mathrm{~mL}$ of methyl bromoacetate (24.2 mmol) were added and the resulting solution was stirred for $4 \mathrm{~h}$ under reflux. After cooling to room temperature, the solvent was removed under reduced pressure and toluene was added to dissolve the remaining oil. The organic phase was washed three times with water and was dried over $\mathrm{MgSO}_{4}$. The solvent was removed under reduced pressure to give yellow oil ( $8.75 \mathrm{~g}, 80 \%$ yield).

${ }^{1} \mathrm{H}$ NMR: $\left(\mathrm{CDCl}_{3}, \mathrm{TMS}, 250 \mathrm{MHz}\right): \delta=1.42\left(\mathrm{~s},-\mathrm{C}-\mathrm{CH}_{3}\right.$, $27 \mathrm{H}), \delta=2.79\left(\mathrm{~m},-\mathrm{N}-\mathrm{CH}_{2}-\mathrm{CH}_{2}-\mathrm{N}, 16 \mathrm{H}\right), \delta=3.24(\mathrm{~s}$, $\left.\mathrm{N}-\mathrm{CH}_{2}-\mathrm{C}=\mathrm{O}-\mathrm{tBu}, 6 \mathrm{H}\right), \delta=3.38\left(\mathrm{~s}, \mathrm{~N}-\mathrm{CH}_{2}-\mathrm{C}=\mathrm{O}-\mathrm{OMe}\right.$, $2 \mathrm{H}), \quad \delta=3.64\left(\mathrm{~s},-\mathrm{O}-\mathrm{CH}_{3}, 3 \mathrm{H}\right)$. ESI-MS: $\mathrm{m} / \mathrm{z}: 587.41$ $[\mathrm{M}+\mathrm{H}]^{+} ; 609.39[\mathrm{M}+\mathrm{Na}]^{+}$.

Synthesis of $\mathrm{DO}_{3} \mathrm{AtBu}$-ethylene Amine Amide $\left(\mathrm{DO}_{3} \mathrm{AtBu}-\mathrm{NH}_{2}\right)$, tert-Butyl 2,2', 2"'-(10-(2-(2-Aminoethylamino)-2-oxoethyl)1,4,7,10-tetraazacyclododecane-1,4,7-triyl)triacetate. $\mathrm{DO}_{3} \mathrm{~A}$ (tert butyl ester)-methylic ester ( $8.75 \mathrm{~g}, 14.9 \mathrm{mmol})$ was dissolved in ethylene diamine $(30 \mathrm{~mL}, 450 \mathrm{mmol})$. The solution was stirred at room temperature for $72 \mathrm{~h}$. The efficiency of the reaction between $\mathrm{DO}_{3} \mathrm{AtBu}-\mathrm{OMe}$ and ethylene diamine was evidenced by mass spectrometry by the complete disappearance of the molecular peak of $\mathrm{DO}_{3} \mathrm{AtBu}-\mathrm{OMe}[(\mathrm{m} / \mathrm{z})=$ $\left.587.41(\mathrm{M}+\mathrm{H})^{+}, 609.39(\mathrm{M}+\mathrm{Na})^{+}\right]$and the appearance of the molecular peak of $\mathrm{DO}_{3} \mathrm{AtBu}-\mathrm{NH}_{2}[(\mathrm{~m} / \mathrm{z})=(\mathrm{M}+\mathrm{H})$, $\left.637.44(\mathrm{M}+\mathrm{Na})^{+}\right]$. After the completion of the reaction $(72 \mathrm{~h})$, the excess of ethylene diamine was removed under reduced pressure. The product was purified by silica gel 
TABLE $1{ }^{1} \mathrm{H}$ NMR and SEC (in $\mathrm{CDCl}_{3}$ and DMF, Respectively) Data of P[PEOMA-st-DO ${ }_{3} \mathrm{AtBuAM}$ ] Copolymers Prepared by RAFT Polymerization

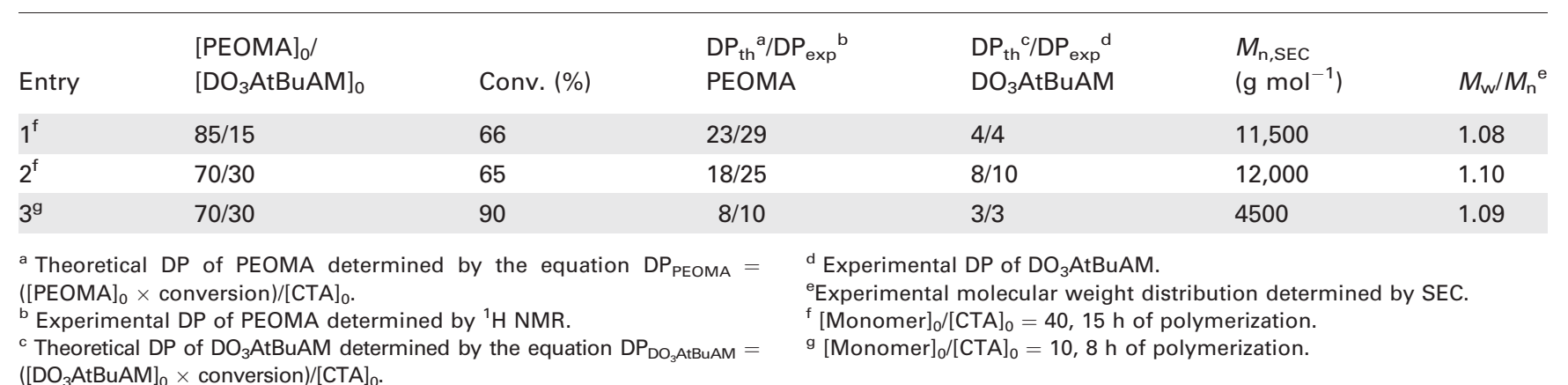

chromatography (gradient from $100 \% \mathrm{CH}_{2} \mathrm{Cl}_{2}$ to $\mathrm{CH}_{2} \mathrm{Cl}_{2}$ / $\mathrm{MeOH} 1: 1)$ and the pure compound $(6.40 \mathrm{~g}, 70 \%$ yield) isolated as white foam.

${ }^{1} \mathrm{H}$ NMR $\left(\mathrm{CDCl}_{3}\right.$, TMS, $\left.250 \mathrm{MHz}\right): \delta=1.42 \mathrm{ppm}\left(\mathrm{s},-\mathrm{C}-\mathrm{CH}_{3}\right.$, $27 \mathrm{H}), 1.80-3.84 \mathrm{ppm}$ (very broad signals with a total integration corresponding to $30 \mathrm{H}$ ), $8.18 \mathrm{ppm}$ (broad, $1 \mathrm{H}$; $\mathrm{C}(\mathrm{O}) \mathrm{NH}) \cdot{ }^{13} \mathrm{C}$ NMR $\left(63 \mathrm{MHz}, \mathrm{TMS}, \mathrm{CDCl}_{3}\right): \delta=27.58 \mathrm{ppm}$ $\left(-\mathrm{C}-\mathrm{CH}_{3}\right), \delta=41.4 \mathrm{ppm}\left(-\mathrm{CH}_{2}-\mathrm{NH}_{2}\right), \delta=42.03 \mathrm{ppm}$ $\left(\mathrm{C}=\mathrm{O}-\mathrm{NH}-\mathrm{CH}_{2}-\right), \delta=51.9,52.91,54.26,55.80 \mathrm{ppm}$ $\left(-\mathrm{CH}_{2}-\mathrm{CH}_{2}-\mathrm{N}-\right), \delta=56.4 \mathrm{ppm}\left(-\mathrm{CH}_{2}-\mathrm{C}=\mathrm{O}-\mathrm{OtBu}\right) \delta=$ 57.73 ppm $\left(-\mathrm{CH}_{2}-\mathrm{C}=\mathrm{O}-\mathrm{NH}-\right), \delta=80.33 \mathrm{ppm}\left(-\mathbf{C}-\mathrm{CH}_{3}\right)$, $\delta=170.06 \mathrm{ppm}(\mathbf{C}=0), \delta=171.97 \mathrm{ppm}(-\mathbf{C}=\mathrm{O}-\mathrm{NH}-)$. ESI-MS: $m / z: 637.44[\mathrm{M}+\mathrm{Na}]^{+}$.

Synthesis of $\mathrm{DO}_{3} \mathrm{AtBuAM}$, tert-Butyl 2,2',2"-(10-(2-(2Acrylamidoethylamino)-2-oxoethyl)-1,4,7,10-tetraazacyclododecane-1,4,7-triyl)triacetate. $\mathrm{DO}_{3} \mathrm{AtBu}-\mathrm{NH}_{2}$ (7.15 mmol, $4.4 \mathrm{~g}$ ) and triethyl amine (10.75 mmol, $1.1 \mathrm{~g}$ ) were dissolved in $100 \mathrm{~mL}$ of dry $\mathrm{CH}_{2} \mathrm{Cl}_{2}$. Acryloyl chloride (8.6 mmol, $0.775 \mathrm{~g}$ ) dissolved in $5 \mathrm{~mL}$ of dry $\mathrm{CH}_{2} \mathrm{Cl}_{2}$ was added dropwise under vigorous stirring to the reaction mixture that was maintained at $0{ }^{\circ} \mathrm{C}$ with an ice bath. After completing the addition, the solution was stirred for $4 \mathrm{~h}$ at room temperature. The product was purified by flash chromatography $(10 \% / 90 \% \mathrm{MeOH} /$ $\mathrm{CH}_{2} \mathrm{Cl}_{2}$ ). The eluate was washed twice with a saturated $\mathrm{NH}_{4} \mathrm{Cl}$ solution and was dried over $\mathrm{MgSO}_{4}$. Finally, the mixture was filtered and was concentrated under reduced pressure to give $3.75 \mathrm{~g}$ of off-white foam (yield 79\%).

${ }^{1} \mathrm{H}$ NMR (TMS, $\left.\mathrm{CDCl}_{3}, 250 \mathrm{MHz}\right) \delta=1.42 \mathrm{ppm}\left(\mathrm{s},-\mathrm{C}-\mathrm{CH}_{3}\right.$, $27 \mathrm{H}), 1.60-3.84 \mathrm{ppm}$ (very broad signals with a total integration corresponding to $28 \mathrm{H}), \delta=5.8$ and $6.5 \mathrm{ppm}$ $\left(\mathrm{CH}_{2}-\mathrm{CH}-\mathrm{C}=\mathrm{O}-, 3 \mathrm{H}\right), 8.7 \mathrm{ppm}$ (broad, $\left.1 \mathrm{H} ; \mathrm{C}(\mathrm{O}) \mathrm{NH}\right)$ and $9.0 \mathrm{ppm}$ (broad, $1 \mathrm{H}, \mathrm{C}(\mathrm{O}) \mathrm{NH}) .{ }^{13} \mathrm{C}$ DEPT 135 (TMS, $\left.\mathrm{CDCl}_{3}, 63 \mathrm{MHz}\right): \delta=27.95 \mathrm{ppm}\left(-\mathrm{C}-\mathrm{CH}_{3}\right), \delta=39.07$ and $39.20 \mathrm{ppm} \quad\left(-\mathrm{C}=\mathrm{O}-\mathrm{NH}-\mathrm{CH}_{2}-\mathrm{CH}_{2}-\right), \delta=52.16 \mathrm{ppm}$ $\left(-\mathrm{CH}_{2}-\mathrm{CH}_{2}-\mathrm{N}-\right), \delta=56.49 \mathrm{ppm}\left(-\mathrm{CH}_{2}-\mathrm{C}=0-\mathrm{OtBu}\right)$, $\delta=125.16 \mathrm{ppm}\left(\mathrm{CH}_{2}=\mathrm{CH}-\mathrm{C}=0\right), \delta=131.63 \mathrm{ppm}$ $\left(\mathrm{CH}_{2}=\mathrm{CH}-\mathrm{C}=0\right)$. ESI-MS: $m / z: 691.42[\mathrm{M}+\mathrm{Na}]^{+}$.

\section{Copolymerization of Poly(ethylene oxide methyl ether acrylate) with $\mathrm{DO}_{3} \mathrm{AtBuAM}$}

$\mathrm{P}$ [PEOMA-st- $\left.\mathrm{DO}_{3} \mathrm{AtBuAM}\right]$, the degree of polymerization (DP) 40; 70 mol \% PEOMA/30 mol \% $\mathrm{DO}_{3} \mathrm{AtBuAM}$ statistical copolymer was synthesized by reversible addition fragmentation chain transfer (RAFT) polymerization of PEOMA and $\mathrm{DO}_{3} \mathrm{AtBuAM}$ as follows. AIBN (0.9 mg, $\left.0.0055 \mathrm{mmol}\right), 20 \mathrm{mg}$ of CTA (0.0548 mmol), $697 \mathrm{mg}$ of PEOMA (1.54 mmol), $440 \mathrm{mg}$ of $\mathrm{DO}_{3} \mathrm{AtBuAM}(0.66 \mathrm{mmol})$, and $3 \mathrm{~mL}$ of DMF were mixed in a $10-\mathrm{mL}$ Schlenk flask. The mixture was degassed by bumbling nitrogen for $5 \mathrm{~min}$. This reaction mixture was heated in an oil bath at $80{ }^{\circ} \mathrm{C}$ for $15 \mathrm{~h}$. The resulting polymer was precipitated twice by adding the solution to large amounts of a heptane/diethyl ether (50/50) mixture under vigorous stirring. The molecular weight composition and conversion were determined by ${ }^{1} \mathrm{H} \mathrm{NMR}$ in $\mathrm{CDCl}_{3}$. Relative molecular weight and polydispersity were measured by size exclusion chromatography (SEC) in DMF using a polyethylene oxide calibration.

${ }^{1} \mathrm{H} \quad \mathrm{NMR} \quad\left(\mathrm{CDCl}_{3}, 250 \mathrm{MHz}, \mathrm{TMS}\right): \delta=0.86 \mathrm{ppm}$ $\left(\mathrm{t},-\mathrm{CH}_{2}-\mathrm{CH}_{3}, 3 \mathrm{H}\right), \delta=1.16 \mathrm{ppm}\left(\mathrm{CH}_{3}-\mathrm{C}-, 6 \mathrm{H}\right), \delta=1.24$ ppm (-CH $\mathrm{CH}_{2}-$ (RAFT), 20H), $\delta=1.43 \mathrm{ppm}\left(\mathrm{s}, \mathrm{CH}_{3}-\mathrm{C}-\right.$, $270 \mathrm{H}$ ), $\delta=3.36 \mathrm{ppm}\left(\mathrm{s}, \mathrm{CH}_{3}-\mathrm{O}-\mathrm{PEO}, 75 \mathrm{H}\right.$ ), $\delta=3.65 \mathrm{ppm}$ (large, $-\mathrm{CH}_{2}-\mathrm{CH}_{2}-\mathrm{O}-, 850 \mathrm{H}$ ), $\delta=4.16$ ppm (large, $\left.-\mathrm{C}=\mathrm{O}-\mathrm{O}-\mathrm{CH}_{2}-\mathrm{PEO}, 50 \mathrm{H}\right) . \quad M_{\mathrm{n}, \mathrm{NMR}}=18,000 \mathrm{~g} \mathrm{~mol}^{-1}$, $\mathrm{DP}_{\mathrm{n}, \mathrm{NMR}}=35, M_{\mathrm{n}, \mathrm{SEC}}=12,000 \mathrm{~g} \mathrm{~mol}^{-1}, M_{\mathrm{w}} / M_{\mathrm{n}}=1.10$, and conversion $=65 \%$.

$\mathrm{P}$ [PEOMA-st- $\left.\mathrm{DO}_{3} \mathrm{AtBuAM}\right]$ with different molecular weights and different compositions were synthesized using the same experimental procedure, except that the RAFT agent to monomer ratio and the ratio between the two monomers were adapted as follows:

P[PEOMA $10^{- \text {st-DO }}$ AtBuAM $_{3}$ ] (Table 1, Entry 3): [PEOMA]/ $\left[\mathrm{DO}_{3} \mathrm{AtBuAM}\right]=7 / 3,\left[\mathrm{PEOMA}+\mathrm{DO}_{3} \mathrm{AtBuAM}\right] /[\mathrm{CTA}]=10$, $[\mathrm{AIBN}] /[\mathrm{CTA}]=0.1 \cdot M_{\mathrm{n}, \mathrm{NMR}}=6500 \mathrm{~g} \mathrm{~mol}^{-1}, \mathrm{DP}_{\mathrm{n}, \mathrm{NMR}}=13$, $M_{\mathrm{n}, \mathrm{SEC}}=4500 \mathrm{~g} \mathrm{~mol}^{-1}, M_{\mathrm{w}} / M_{\mathrm{n}}=1.09$, conversion $90 \%$.

$\mathrm{P}\left[\mathrm{PEOMA}_{29}\right.$-st-DO $\left.{ }_{3} \mathrm{AtBuAM}_{4}\right]$ (Table 1, Entry 1): [PEOMA]/ $\left[\mathrm{DO}_{3} \mathrm{AtBuAM}\right]=85 / 15,\left[\mathrm{PEOMA}+\mathrm{DO}_{3} \mathrm{AtBuAM}\right] /[\mathrm{CTA}]=40$, $[\mathrm{AIBN}] /[\mathrm{CTA}]=0.1 . M_{\mathrm{n}, \mathrm{NMR}}=15,800 \mathrm{~g} \mathrm{~mol}^{-1}, \mathrm{DP}_{\mathrm{n}, \mathrm{NMR}}=33$, $M_{\mathrm{n}, \mathrm{SEC}}=11,000 \mathrm{~g} \mathrm{~mol}^{-1}, M_{\mathrm{w}} / M_{\mathrm{n}}=1.08$, and conversion $66 \%$.

\section{Formation of the Macromolecular Contrast Agent}

Typically, $1 \mathrm{~g}$ of the copolymer P[PEOMA 25 -st-DO $\left.{ }_{3} \mathrm{AtBuAM}_{10}\right]$ (Table 1, Entry 2) was dissolved in trifluoroacetic acid (TFA; $10 \mathrm{~mL}$ ) and stirred overnight at room temperature to remove the tert-butyl groups of protected $\mathrm{DO}_{3} \mathrm{AtBu}$. The solution was evaporated to dryness and the residue was dissolved in water $(15 \mathrm{~mL}) \cdot \mathrm{GdCl}_{3} \cdot 6 \mathrm{H}_{2} \mathrm{O}(230 \mathrm{mg}, 0.620 \mathrm{mmol}$, 
1.1 equiv compared with the $\mathrm{DO}_{3} \mathrm{AAM}$ function) was added to this solution and the $\mathrm{pH}$ was adjusted to 6 by the addition of $1 \mathrm{M} \mathrm{KOH}$ solution. The reaction mixture was heated overnight at $40{ }^{\circ} \mathrm{C}$. The uncomplexed $\mathrm{Gd}^{3+}$ ions were removed by the addition of DOTA solution $(0.1 \mathrm{M}, \mathrm{pH}=6)$ followed by dialysis (Spectra/Por, molecular weight cut-off 6000/8000) against water for $96 \mathrm{~h}$. Water was then evaporated to dryness under reduced pressure and the macromolecular complex $\left(\mathrm{P}\left[\mathrm{PEOMA} \mathrm{A}_{25}\right.\right.$-st- $\left.\left.\mathrm{DO}_{3} \mathrm{AAM}\left(\mathrm{Gd}^{3+}\right)_{10}\right]\right)$ was obtained as pale yellow oil (1.1 g). The macromolecular CA (20 mg) was dissolved in water $(2 \mathrm{~mL})$ and analyzed by relaxometry.

Preparation of the $\mathrm{Gd}^{3+}$ Complex with 1-(5-Amino-3-aza-2oxopentyl)-4,7,10-tris(carbonylmethyl)-1,4,7,10-tetraazacyclododecane, $\mathrm{GdDO}_{3} \mathrm{~A}-\mathrm{NH}_{2}$

The ligand $\left(\mathrm{DO}_{3} \mathrm{AtBu}-\mathrm{NH}_{2} ; 200 \mathrm{mg}, 0.325 \mathrm{mmol}\right)$ was dissolved in TFA ( $3 \mathrm{~mL}$ ) and was stirred overnight at room temperature. The solvent was evaporated under reduced pressure and the ligand was dissolved in water $(5 \mathrm{~mL})$. $\mathrm{GdCl}_{3} \cdot 6 \mathrm{H}_{2} \mathrm{O}$ (133 $\mathrm{mg}, 0.36 \mathrm{mmol}$ ) was added to this solution and the $\mathrm{pH}$ was adjusted to 6 by the addition of $1 \mathrm{M} \mathrm{KOH}$ solution. The solution was heated overnight at $40{ }^{\circ} \mathrm{C}$. Finally, the uncomplexed $\mathrm{Gd}^{3+}$ ions were removed by eluting the solution through a chelex 100 (Bio-Rad Laboratories, sodium form) resin. The resulting solution was brought to dryness under reduced pressure and the $\mathrm{GdDO}_{3} \mathrm{~A}-\mathrm{NH}_{2}$ complex was recovered as pale yellow solid in almost quantitative yield (>95\%). MS (ESI): $m / z: 602.15[\mathrm{M}-\mathrm{H}]^{+}$.

\section{Polymerization of 2-Hydroxyethyl acrylate (PHEA)}

PHEA (DP50) was synthesized by RAFT polymerization of 2-hydroxyethyl acrylate (HEA) as follows. 2,2'-Azobis(isobutyronitrile) (AIBN; $9 \mathrm{mg}, 0.055 \mathrm{mmol}$ ), $200 \mathrm{mg}$ of CTA (0.55 mmol), $3.19 \mathrm{~g}$ of HEA (27.5 mmol), and $7 \mathrm{~mL}$ of DMF were mixed in a 25-mL Schlenk flask. The mixture was degassed by bumbling nitrogen. This reaction mixture was heated in an oil bath at $80{ }^{\circ} \mathrm{C}$ for $4 \mathrm{~h}$. The polymer was precipitated twice by adding the solution into a large volume of a heptane/diethyl ether mixture (50/50). The molecular weight composition and conversion percentage were determined by ${ }^{1} \mathrm{H}$ NMR in $\mathrm{CDCl}_{3}$. Relative molecular weights $\left(M_{\mathrm{n}, \mathrm{SEC}}\right)$ and polydispersity were measured by SEC in DMF/LiBr using a polyethylene oxide calibration. Conversion $>98 \%$.

${ }^{1} \mathrm{H}$ NMR ( $\left.\mathrm{CDCl}_{3}, 250 \mathrm{MHz}, \mathrm{TMS}\right): \delta=0.86 \mathrm{ppm}\left(\mathrm{t},-\mathrm{CH}_{2}-\mathrm{CH}_{3}\right.$, $3 \mathrm{H}), \quad \delta=1.16 \mathrm{ppm}\left(\mathrm{CH}_{3}-\mathrm{C}-, 6 \mathrm{H}\right), \delta=1.24 \mathrm{ppm}$ (- $\mathrm{CH}_{2}-$ (RAFT), 20H), $\delta=1.62-1.89 \mathrm{ppm}$ (large, $-\mathrm{CH}_{2}-\mathrm{CH}$, $110 \mathrm{H}), \delta=2.30 \mathrm{ppm}$ (large, $\left.-\mathrm{CH}_{2}-\mathrm{CH}-, 55 \mathrm{H}\right), \delta=3.72 \mathrm{ppm}$ (large, $-\mathrm{CH}_{2}-\mathrm{CH}_{2}-\mathrm{OH}, 110 \mathrm{H}$ ), $\delta=4.16$ ppm (large, $\left.-\mathrm{C}(=\mathrm{O})-\mathrm{O}-\mathrm{CH}_{2}-\mathrm{CH}_{2}-\mathrm{OH}, 110 \mathrm{H}\right), M_{\mathrm{n}, \mathrm{NMR}}=6400 \mathrm{~g} \mathrm{~mol}^{-1}$, $\mathrm{DP}_{\mathrm{n}, \mathrm{NMR}}=55, M_{\mathrm{n}, \mathrm{SEC}}=6000 \mathrm{~g} \mathrm{~mol}^{-1}, M_{\mathrm{w}} / M_{\mathrm{n}}=1.12$.

\section{Characterizations}

${ }^{1} \mathrm{H}$ and ${ }^{13} \mathrm{C}$ NMR spectra of the different polymers were recorded at $298 \mathrm{~K}$ with a Bruker spectrometer $(250 \mathrm{MHz} ; 63$ $\mathrm{MHz}$ for $13 \mathrm{C}$ ) in $\mathrm{CDCl}_{3}$ or $d_{6}$-DMSO [(D1) $2 \mathrm{~s}, 16$ scans, $5 \mathrm{wt}$ $\%$ of polymer or $10 \mathrm{wt} \%$ of organic compound].

SEC of the polymers was carried out in dimethylformamide containing $25 \mathrm{mM} \mathrm{LiBr}$ (flow rate: $1 \mathrm{~mL} \mathrm{~min}^{-1}$ ) at $55{ }^{\circ} \mathrm{C}$ with a Waters 600 liquid chromatograph equipped with a 410 refractive index detector and four Waters Styragel columns [HR 1 (100-5000), HR 3 (500-30,000), HR 4 (5000500,000), and HR 5 (2000-4,000,000; $7.8 \mathrm{~mm} \times 300 \mathrm{~mm})]$. Polyethylene oxide standards were used for calibration.

Electrospray mass spectra were obtained on a Bruker Daltonics MicrOTOF (TOF-ESI-MS) spectrometer.

Field cycling relaxometry. The water proton nuclear magnetic relaxation dispersion (NMRD) profiles were measured at $25{ }^{\circ} \mathrm{C}$ in nondeuterated water on a Stelar Fast Field-Cycling Spectrometer FFC-2000 equipped with a permanent magnet for the relaxation measurements in the $15-80 \mathrm{MHz}$ range. The ${ }^{1} \mathrm{H} T_{1}$ relaxation times were acquired by the standard inversion recovery method with a typical $90^{\circ}$ pulse width of $3.5 \mu \mathrm{s}$, using 16 experiments of four scans. The NMRD profiles were measured in the range of magnetic fields from 0.0002 to $1.88 \mathrm{~T}$ (corresponding to $0.01-80 \mathrm{MHz}$ proton Larmor frequencies).

Inductive coupling plasma (ICP). The gadolinium concentration of the modified copolymer was determined by inductively coupled plasma mass spectrometry (ICP-MS), carried out with a spectrometer (DRC II, Perkin-Elmer). Samples were prepared by reaction of $1.5 \mathrm{~mL}$ of a macrocontrast agent solution with $2 \mathrm{~mL}$ of $\mathrm{HNO}_{3}(65 \%)$ at room temperature for $2 \mathrm{~h}$. The solution was then diluted to $100 \mathrm{~mL}$ with bidistilled water before ICP-MS analysis.

Dynamic light scattering (DLS). Copolymers were analyzed for their size distribution using a Malvern Zetasizer ${ }^{\circledR}$ Nano Series DTS 1060 (Malvern instruments S.A., Worcestershire, UK). Concentrations of copolymers were adjusted to $2.5 \mathrm{mg} \mathrm{mL}^{-1}$ in a solution composed of $750 \mu \mathrm{L}$ of deionized water and $250 \mu \mathrm{L}$ of Veronal-buffered saline containing $0.15 \mathrm{mM} \mathrm{Ca}^{2+}$ and $0.5 \mathrm{mM} \mathrm{Mg}^{2+}$ to ensure a convenient scattered intensity on the detector.

Complement consumption testing (CH50 test). The complement consumption was assessed in normal human serum (provided by the Etablissement Français du Sang, CHU, Angers, France) by measuring the residual hemolytic capacity of the complement system. The technique consisted in determining the amount of serum able to lyse $50 \%$ of a fixed number of sensitized sheep erythrocytes with rabbit antisheep erythrocyte antibodies (CH50), according to the procedure described elsewhere. ${ }^{23,24}$ The complement activation was expressed as a function of the surface to compare polymeric particles with different mean diameters. Nanoparticle surface areas were calculated as described elsewhere, ${ }^{25}$ using the equations: $S=n 4 \pi r^{2}$ and $V=n(4 / 3)\left(\pi r^{3}\right)$ leading to $S=3 m / r \rho$, where $S$ is the surface area $\left(\mathrm{cm}^{2}\right)$ and $V$ the volume $\left(\mathrm{cm}^{3}\right)$ of $n$ spherical beads of average radius $r(\mathrm{~cm})$, weight $m(\mu \mathrm{g})$, and volumetric mass $\rho\left(\mu \mathrm{g} \mathrm{cm}^{-3}\right)$.

\section{RESULTS AND DISCUSSION}

\section{Synthesis of the Macrocontrast Agent P[PEOMA-st-DO $\left.{ }_{3} \mathrm{~A}\left(\mathrm{Gd}^{3+}\right) \mathrm{AM}\right]$}

Scheme 2 summarizes the general procedure adopted for the synthesis of the macrocontrast agent. First, the tert-butyl 


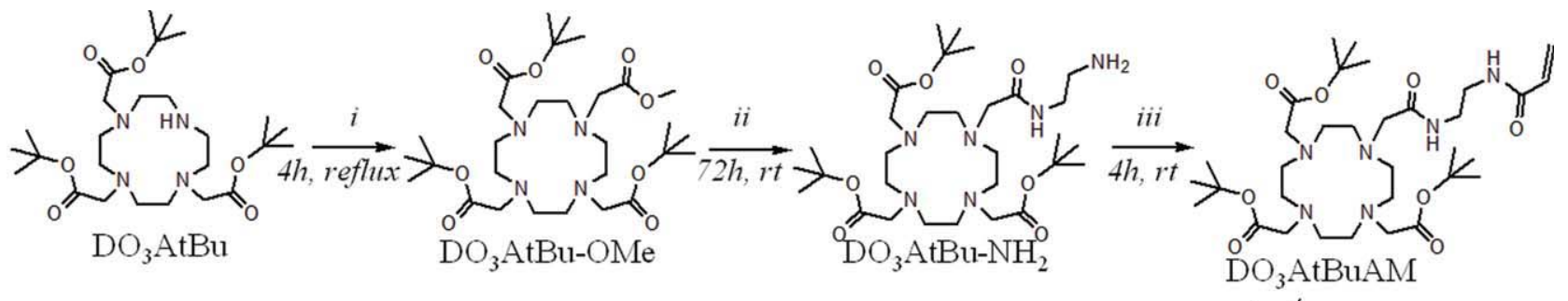

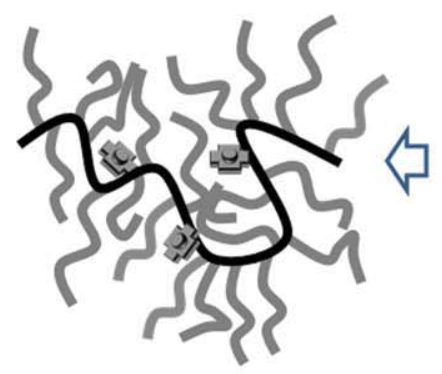

'Macrocontrast agent'

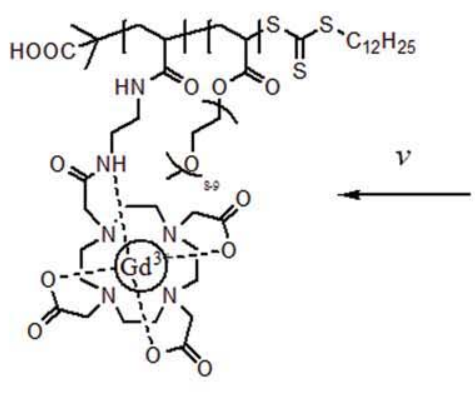

P[PEOMA-st-DO $\left.{ }_{3} \mathrm{~A}\left(\mathrm{Gd}^{3+}\right) \mathrm{AM}\right]$

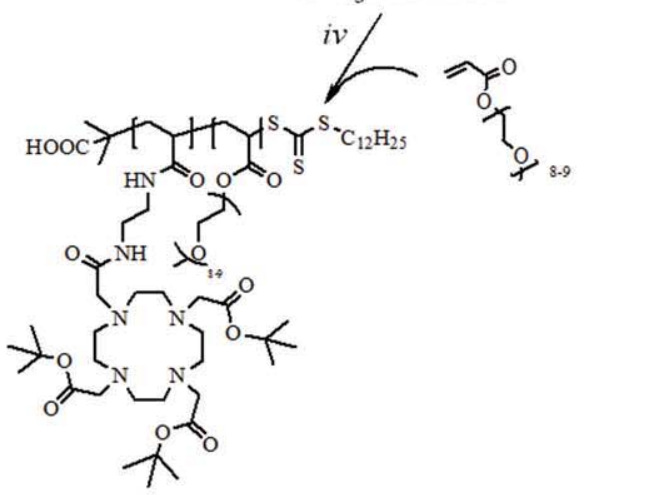

$\mathrm{P}$ [PEOMA-st-DO $\mathrm{AtBuAM}_{3}$

$$
\begin{aligned}
& i \text { : Methyl bromoacetate, } \mathrm{K}_{2} \mathrm{CO}_{3}, \mathrm{ACN}, 80 \% \text { ii : Ethylenediamine, } 70 \% \text { iii : Acrylic chloride, TEA; } \mathrm{CH}_{2} \mathrm{Cl}_{2}, 79 \% \\
& \text { iv: CTA, } \mathrm{AIBN}(10 \%) \text {; DMF } \quad v \text { : a)TFA b) } \mathrm{Gd}^{3+}, \mathrm{KOH}
\end{aligned}
$$

SCHEME 2 General procedure for the synthesis of the macromolecular CA by "grafting through" method.

ester of 2,2', $2^{\prime \prime}$-(1,4,7,10-tetraazacyclododecane-1,4,7-triyl)triacetic acid $\left(\mathrm{DO}_{3} \mathrm{AtBu}\right)$ was functionalized with a $\mathrm{N}$-(2-propionamidoethyl)acrylamide group in three steps to obtain $\mathrm{DO}_{3} \mathrm{AtBuAM}$. This new macrocyclic ligand was then copolymerized with PEOMA using RAFT process. CTA was the RAFT agent, ${ }^{22}$ and the polymerization was performed in the presence of $10 \mathrm{~mol} \% \mathrm{AIBN}$ at $80^{\circ} \mathrm{C}$ in DMF. Finally, the tert-butyl groups were removed with TFA and the complexation of $\mathrm{Gd}^{3+}$ ions was carried out at $\mathrm{pH} 6$ and $40{ }^{\circ} \mathrm{C}$ for $10 \mathrm{~h}$. The excess of free $\mathrm{Gd}^{3+}$ ions was removed by the addition of $2,2^{\prime}, 2^{\prime \prime}, 2^{\prime \prime \prime}-(1,4,7,10$-tetraazacyclododecane-1,4, 7,10-tetrayl) tetraacetic acid (DOTA), a ligand known to strongly complex lanthanide ions. This was followed by dialysis of the copolymer against water and by freeze-drying the final product. The content of gadolinium immobilized onto the copolymers was determined by ICP-MS.

Two different PEOMA/DO ${ }_{3}$ AtBuAM molar ratios $(85 / 15$ and 70/30) were considered as well as two different DPs $=40$ and 10 (Table 1). The monomer conversion, copolymer composition, and molecular weights were obtained by ${ }^{1} \mathrm{H}$ NMR spectroscopy. The experimental molecular weights of the purified copolymers were determined by comparison of the resonance integrals at $4.19 \mathrm{ppm}$ of $\left(-\mathrm{C}(=0)-0-\mathrm{CH}_{2}-\mathrm{PEO}\right)$ and $1.43 \mathrm{ppm}$ of tert-butyl $\left(-\mathrm{C}-\left(\mathrm{CH}_{3}\right)_{3}\right)$ of $\mathrm{DO}_{3} \mathrm{AtBuAM}$ with the integrals at $0.86 \mathrm{ppm}$ corresponding to the $\omega$ chainend (Fig. 1) $\left[-\left(\mathrm{CH}_{2}\right)_{11}-\mathrm{CH}_{3}\right]$. They were in good agreement with the theoretical values (Table 1), and the polydispersity of the copolymers determined by SEC was low $\left(M_{\mathrm{w}} / M_{\mathrm{n}}<1.1\right.$;
Table 1) as expected for a controlled process. The SEC chromatograms are also monomodal (Fig. 2).

\section{Relaxivities of the Macrocontrast Agents P[PEOMA-st-DO $\left.{ }_{3} \mathrm{~A}\left(\mathrm{Gd}^{3+}\right) \mathrm{AM}\right]$}

The contrast efficiencies of all the synthesized macrocontrast agents are compared in Table 2 . The relaxivity $\left(r_{1}\right)$ of each CA is calculated after measuring longitudinal relaxation time $\left(T_{1}\right)$ according to

$$
\frac{1}{T_{1 \mathrm{obs}}}=r_{1}\left[\mathrm{Gd}^{3+}\right]+\frac{1}{T_{1 \mathrm{H}_{2} \mathrm{O}}}
$$

where $T_{1}$ obs and $T_{1 \mathrm{H}_{2} \mathrm{O}}$ are the longitudinal relaxation times in the presence and absence (2.86 s) of the MRI CA, respectively, and $\left[\mathrm{Gd}^{3+}\right]$ is the concentration of the CA in millimolar.

The relaxivities $\left(r_{1}\right)$ of the different macrocontrast agents at $20 \mathrm{MHz}$ range from 12.2 to $14.5 \mathrm{mM}^{-1} \mathrm{~s}^{-1}$ and are about 2.3-2.8 times higher than that of the free $\mathrm{DO}_{3} \mathrm{~A}\left(\mathrm{Gd}^{3+}\right)-\mathrm{NH}_{2}$ complex taken here as a reference (Table 2). This relaxivity increase is due to the reduced tumbling rates of Gd chelates attached to the macromolecule. ${ }^{26}$

Full relaxometric data were measured for P[PEOMA 25 -st$\mathrm{DO}_{3} \mathrm{~A}\left(\mathrm{Gd}^{3+}\right) \mathrm{AM}_{10}$ ] (Table 2, Entry 2) over a large magnetic field range (from $0.01 \mathrm{MHz}$ to $100 \mathrm{MHz}$ ) and are compared with $\mathrm{DO}_{3} \mathrm{~A}\left(\mathrm{Gd}^{3+}\right)-\mathrm{NH}_{2}$ in Figure 3. At low frequencies (0.01-5 MHz), the relaxivity is about 1.5 higher than that of free $\mathrm{DO}_{3} \mathrm{~A}\left(\mathrm{Gd}^{3+}\right)-\mathrm{NH}_{2}$. The effect of the immobilization of 

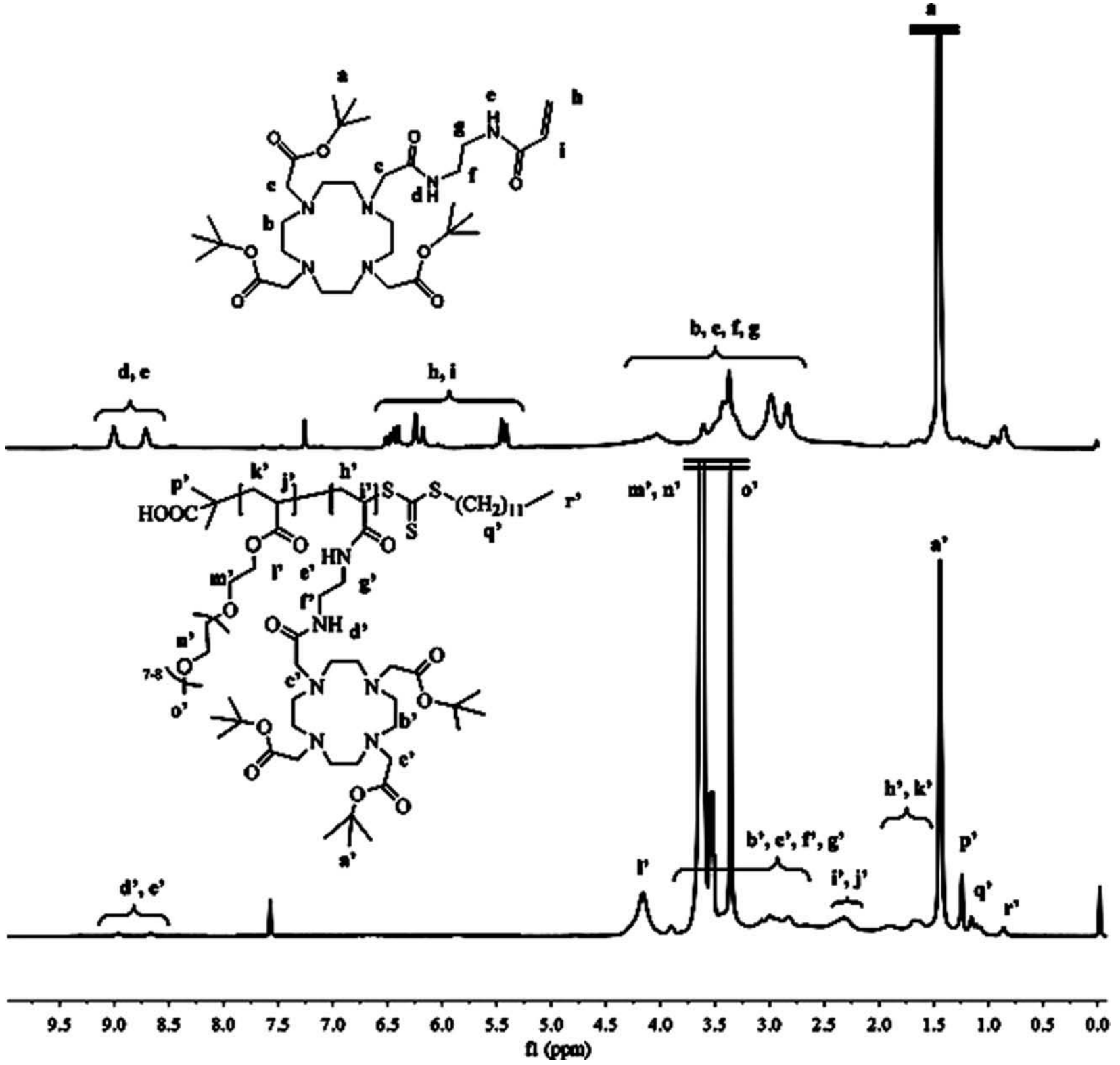

FIGURE $1{ }^{1} \mathrm{H}$ NMR spectra of $\mathrm{DO}_{3} \mathrm{AtBuAM}$ (up) and P[PEOMA ${ }_{25}$-st-DO $\left.{ }_{3} \mathrm{AtBuAM}_{10}\right]$.

gadolinium on macromolecules has an even more pronounced effect on the relaxivity at high frequencies (10-80 MHz). As shown in Figure 3, the maximum relaxivity for the best macrocontrast agent $\mathrm{P}\left[\mathrm{PEOMA} \mathrm{P}_{25}\right.$-st$\mathrm{DO}_{3} \mathrm{~A}\left(\mathrm{Gd}^{3+}\right) \mathrm{AM}_{10}$ ] (Table 2, Entry 2) is obtained at $40 \mathrm{MHz}$ $\left(r_{1}=14.9 \mathrm{mM}^{-1} \mathrm{~s}^{-1}\right)$ with a $300 \%$ relaxivity increase compared with free $\mathrm{DO}_{3} \mathrm{~A}\left(\mathrm{Gd}^{3+}\right)-\mathrm{NH}_{2}\left(r_{1}=4.6 \mathrm{mM}^{-1} \mathrm{~s}^{-1}\right)$. This relaxivity value is in the same range as that measured for macrocontrast agents based on micelles $\left(r_{1}=11.9\right.$ $\left.\mathrm{mM}^{-1} \mathrm{~s}^{-1}\right),{ }^{19}$ twice-higher compared with Gd chelates immobilized on polyacrylic nanoparticles $\left(r_{1}=6.8 \mathrm{mM}^{-1} \mathrm{~s}^{-1}\right){ }^{27}$ and remains slightly lower than that of dendrimer based Gd chelates $\left(r_{1}=17.3 \mathrm{mM}^{-1} \mathrm{~s}^{-1}\right.$ at $\left.37{ }^{\circ} \mathrm{C}\right) .{ }^{28}$

It should be noted here that the percentage of $\mathrm{DO}_{3} \mathrm{~A}$ (and thus of $\mathrm{Gd}^{3+}$ ) in copolymers with similar molecular weights has little influence on the relaxivity at $20 \mathrm{MHz}$ (Table 2, Entries 1 and 2). On the other hand, an increase of the molecular weight of the copolymers slightly improves the relaxivity as expected because the tumbling of the macrocontrast agents becomes slower, in agreement with the work of Karfeld-Sulzer et al. ${ }^{20}$ This modest relaxivity increase suggests that the $\mathrm{DO}_{3} \mathrm{~A}$ ligand attached to the macromolecule possesses a fairly high mobility. The spacer between the ligand and the macromolecule backbone might be shortened to improve this relaxivity.

\section{Complement Activation Test}

The improvement of relaxivity by attaching a ligand to a macromolecule is a first way to improve the CA efficiency. A second one consists in avoiding its recognition by the immune system to avoid a rapid elimination from the blood 


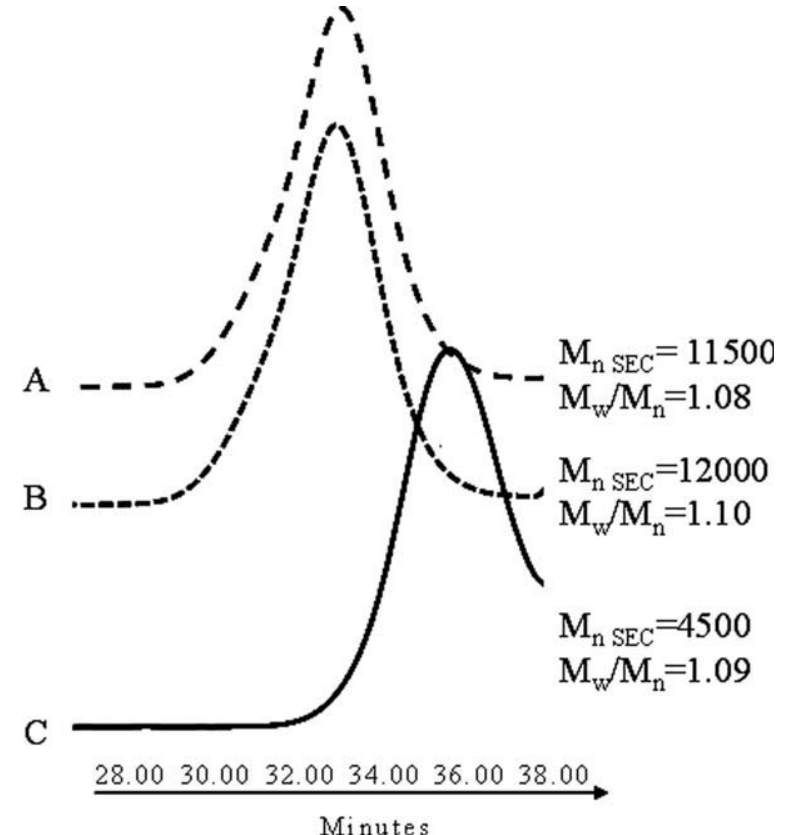

FIGURE 2 Size exclusion chromatograms in DMF of P[PEOMAst-DO ${ }_{3}$ AtBuAM]; A: Table 1, Entry 1; B: Table 1, Entry 2; and C: Table 1, Entry 3.

circulation. PEO grafts on our P[PEOMA-st-DO $\left.{ }_{3} \mathrm{~A}\left(\mathrm{Gd}^{3+}\right) \mathrm{AM}\right]$ macrocontrast agents should therefore ensure this role due to their well-known stealth character.

$\mathrm{P}\left[\mathrm{PEOMA}_{25}-\mathrm{st}-\mathrm{DO}_{3} \mathrm{~A}\left(\mathrm{Gd}^{3+}\right) \mathrm{AM}_{10}\right]$ macrocontrast agent and its precursor $\mathrm{P}\left[\mathrm{PEOMA}_{25}-\mathrm{st}-\mathrm{DO}_{3} \mathrm{AtBuAM} \mathrm{M}_{10}\right]$ were first dissolved in water $\left(2.5 \mathrm{mg} \mathrm{mL}^{-1}\right.$; see the section "Experimental Procedures") and analyzed by DLS. Although P[PEOMA-st-DO ${ }_{3}$ At$\mathrm{BuAM}$ ] forms micelles with an average diameter of $200 \mathrm{~nm}$ due to the presence of hydrophobic domains ( $\left.\mathrm{DO}_{3} \mathrm{AtBuAM}\right)$ inside the hydrophilic polymer, the macrocontrast agent is fully water soluble with an average size of $25 \mathrm{~nm}$ (Fig. 4).

TABLE 2 Data of P[PEOMA-st-DO $\left.{ }_{3} \mathrm{~A}\left(\mathrm{Gd}^{3+}\right) \mathrm{AM}\right]$ and Their Relaxivities Compared with Free $\mathrm{DO}_{3} \mathrm{~A}\left(\mathrm{Gd}^{3+}\right)-\mathrm{NH}_{2}$ as Reference at $20 \mathrm{MHz}$ and $25^{\circ} \mathrm{C}$

\begin{tabular}{|c|c|c|c|}
\hline Entry & $\begin{array}{l}\text { (Macro)contrast } \\
\text { Agents }\end{array}$ & $\begin{array}{l}\text { Relaxivity } \\
\text { per } \mathrm{Gd}^{3+a} \\
\left(\mathrm{mM}^{-1} \mathrm{~s}^{-1}\right)\end{array}$ & $\begin{array}{l}\text { Relaxivity } \\
\text { per Polymer } \\
\left(\mathrm{mM}^{-1} \mathrm{~s}^{-1}\right)\end{array}$ \\
\hline \multirow[t]{2}{*}{1} & $\begin{array}{l}\mathrm{P}\left[\mathrm{PEOM} \mathrm{A}_{29} \text {-st- } \mathrm{DO}_{3} \mathrm{~A}\right. \\
\left.\left(\mathrm{Gd}^{3+}\right) \mathrm{AM}_{4}\right]\end{array}$ & $14.2( \pm 0.1)$ & $56.8( \pm 0.1)$ \\
\hline & $M_{\mathrm{n}}=15,800 \mathrm{~g} \mathrm{~mol}^{-1}$ & & \\
\hline \multirow[t]{2}{*}{2} & $\begin{array}{l}\mathrm{P}\left[\mathrm{PEOMA} \mathrm{A}_{25}-\mathrm{st}-\mathrm{DO}_{3} \mathrm{~A}\right. \\
\left.\left(\mathrm{Gd}^{3+}\right) \mathrm{AM}_{10}\right]\end{array}$ & $14.5( \pm 0.1)$ & $145( \pm 0.1)$ \\
\hline & $M_{\mathrm{n}}=18,000 \mathrm{~g} \mathrm{~mol}^{-1}$ & & \\
\hline \multirow[t]{2}{*}{3} & $\begin{array}{l}\mathrm{P}\left[\mathrm{PEOMA} \mathrm{A}_{10}-\mathrm{st}-\mathrm{DO}_{3} \mathrm{~A}\right. \\
\left.\left(\mathrm{Gd}^{3+}\right) \mathrm{AM}_{3}\right]\end{array}$ & $12.2( \pm 0.1)$ & $36.6( \pm 0.1)$ \\
\hline & $M_{\mathrm{n}}=6500 \mathrm{~g} \mathrm{~mol}^{-1}$ & & \\
\hline 4 & $\mathrm{DO}_{3} \mathrm{~A}\left(\mathrm{Gd}^{3+}\right)-\mathrm{NH}_{2}$ & $5.2( \pm 0.1)$ & $5.2( \pm 0.1)$ \\
\hline
\end{tabular}

${ }^{\mathrm{a}}$ At $20 \mathrm{MHz}$ and $25^{\circ} \mathrm{C}$.

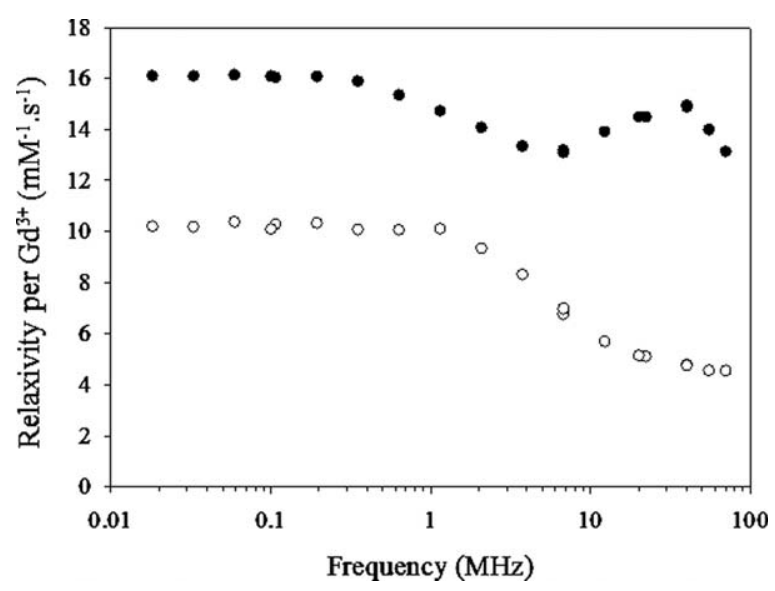

FIGURE 3 Comparison of the ${ }^{1} \mathrm{H} \quad$ NMRD profiles of $\mathrm{DO}_{3} \mathrm{~A}\left(\mathrm{Gd}^{3+}\right)-\mathrm{NH}_{2}$ (empty circles) and P[PEOMA ${ }_{25}$-st$\mathrm{DO}_{3} \mathrm{~A}\left(\mathrm{Gd}^{3+}\right) \mathrm{AM}_{10}$ ] (Table 2, Entry 2; full circles).

The recognition of the macromolecular CA by the immune system was then evaluated by the hemolytic CH50 test and was compared with poly(2-hydroxyethyl acrylate) used here as a positive control. Interestingly, Figure 5 clearly shows that the macromolecular CA synthesized by the grafting through method does not activate the complement. This very low activation means that the macromolecular CA is expected to have a long blood circulation time, resulting from the stealth PEO brush that hides efficiently the gadolinium complex (Scheme 2).

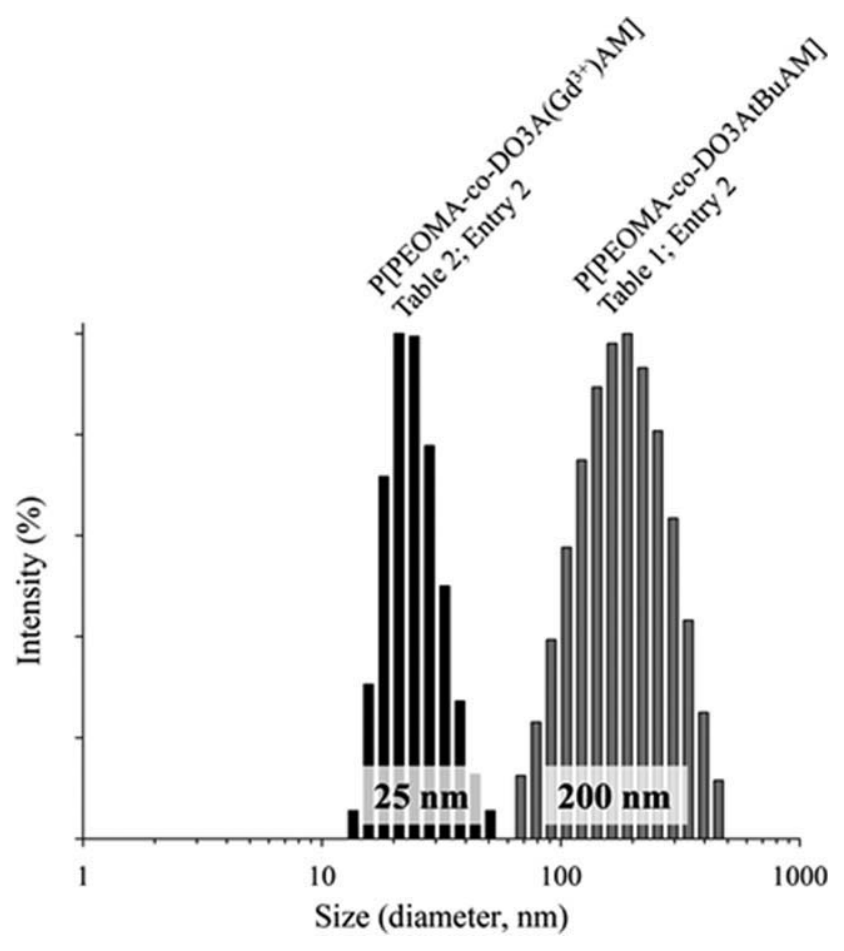

FIGURE 4 DLS of P[PEOMA ${ }_{25}-$ st-DO $_{3} \mathrm{~A}\left(\mathrm{Gd}^{3+}\right) \mathrm{AM}_{10}$ ] (Table 2, Entry 2) and its precursor P[PEOMA ${ }_{25}-\mathrm{st}-\mathrm{DO}_{3} \mathrm{AtBuAM}_{10}$ ] (Table 1, Entry 2). 

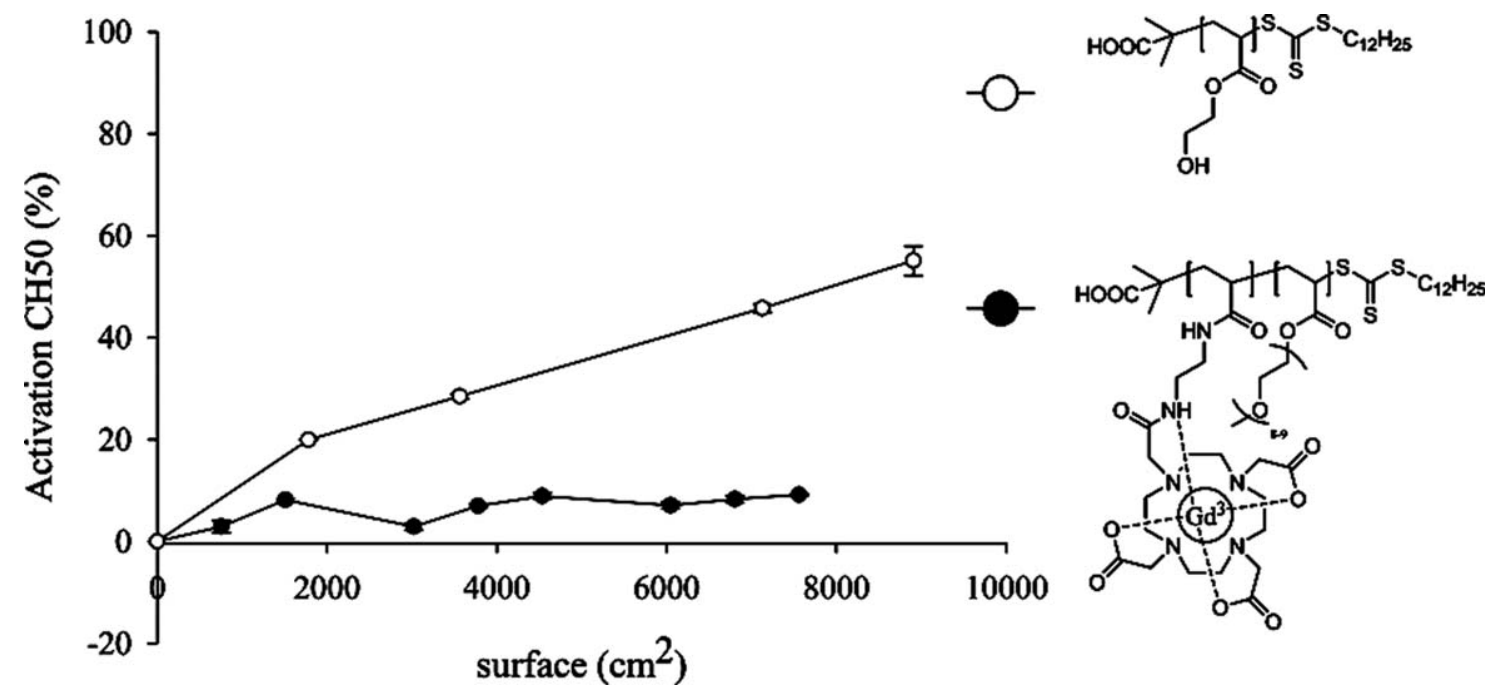

FIGURE 5 Consumption of $\mathrm{CH} 50$ units in the presence of $\mathrm{PHEA}_{55}$ and $\mathrm{P}\left[\mathrm{PEOMA} \mathrm{A}_{25}-\mathrm{st}-\mathrm{DO}_{3} \mathrm{~A}\left(\mathrm{Gd}^{3+}\right) \mathrm{AM}_{10}\right]$ as a function of surface area.

Furthermore, it is very important to note that the stability of macrocyclic compounds such as $\mathrm{DO}_{3} \mathrm{~A}$ is characterized by slow kinetics of decomplexation (dissociation half-life at $\mathrm{pH} 7.4, t_{1 / 2}>1000$ years). ${ }^{29}$ This very slow decomplexation is therefore suitable for safely biological uses.

\section{CONCLUSIONS}

Well-defined stealthy MRI CAs were synthesized by a grafting through method by RAFT copolymerization of an acrylamide functionalized ligand ( $\left.\mathrm{DO}_{3} \mathrm{AtBuAM}\right)$ with PEOMA. By adjusting the copolymerization conditions, the molecular weight of the macrocontrast agent and their content in gadolinium chelates can be easily tuned. Relaxivity was enhanced by $300 \%$ compared with the free gadolinium chelate $\left(\mathrm{DO}_{3} \mathrm{~A}\left(\mathrm{Gd}^{3+}\right)-\mathrm{NH}_{2}\right)$ at high frequencies. These results suggest that the restricted tumbling of the $\mathrm{Gd}^{3+}$ complexes (caused by their attachment to the polymer backbone) contributes to an improved relaxivity at high frequency in consistency with the theory of relaxivity. Moreover, the hemolytic CH50 test has demonstrated that PEO grafts on the macrocontrast agent prevent its recognition by the immune system by hiding the gadolinium chelates. This observation suggests that the PEO-modified macrocontrast agent should have long blood circulation.

C. Detrembleur, M. Grogna, and C. Jérôme are much indebted to the "Politique Scientifique Fédérale" for financial support in the frame of the "Interuniversity Attraction Pôles Programme (IAP VI/27): Supramolecular Chemistry and Supramolecular Catalysis" to University of Liège and to the National Funds for Scientific Research (F.R.S.-FNRS). The authors also thank Jérôme Bejaud [Ingénierie de la Vectorisation Particulaire (Inserm), Angers, France] for skilful assistance in the CH50 tests. J.-F. Desreux gratefully thanks the FNRS and the IISN of Belgium for financial support.

\section{REFERENCES AND NOTES}

1 Villaraza, A. J. L.; Bumb, A.; Brechbiel, M. W. Chem Rev 2010, 110, 2921-2959.
2 Caravan, P.; Ellison, J. J.; McMurry, T. J.; Lauffer, R. B. Chem Rev 1999, 99, 2293-2352.

3 Doiron, A. L.; Chu, K.; Ali, A.; Brannon-Peppas, L. Proc Natl Acad Sci USA 2008, 105, 17232-17237.

4 Battistini, E.; Gianolio, E.; Gref, R.; Couvreur, P.; Fuzerova, S.; Othman, M.; Aime, S.; Badet, B.; Durand, P. Chem-Eur J 2008, 14, 4551-4561.

5 Voisin, P.; Ribot, E. J.; Miraux, S.; Bouzier-Sore, A.-K.; Lahitte, J.-F.; Bouchaud, V.; Mornet, S.; Thiaudiere, E.; Franconi, J.-M.; Raison, L.; Labrugere, C.; Delville, M.-H. Bioconjugate Chem 2007, 18, 1053-1063.

6 Warsi, M. F.; Adams, R. W.; Duckett, S. B.; Chechik, V. Chem Commun 2010, 46, 451-453.

7 Solomon, I. Phys Rev 1955, 99, 559-565.

8 Bloembergen, N. J Chem Phys 1957, 27, 572-573.

9 Passirani, C.; Benoit, J.-P. Biomater Delivery Targeting Proteins Nucleic Acids 2005, 187-230.

10 Fox, M. E.; Szoka, F. C.; Frechet, J. M. J. Acc Chem Res 2009, 42, 1141-1151.

11 Venkatachalam, M. A.; Rennke, H. G. Circ Res 1978, 43, 337-347.

12 Caravan, P.; Parigi, G.; Chasse, J. M.; Cloutier, N. J.; Ellison, J. J.; Lauffer, R. B.; Luchinat, C.; McDermid, S. A.; Spiller, M.; McMurry, T. J. Inorg Chem 2007, 46, 6632-6639.

13 Sieving, P. F.; Watson, A. D.; Rocklage, S. M. Bioconjugate Chem 1990, 1, 65-71.

14 Spanoghe, M.; Lanens, D.; Dommisse, R.; Van der Linden, A.; Alder Weireldt, F. Magn Reson Imaging 1992, 10, 913-917.

15 Kobayashi, H.; Brechbiel, M. W. Adv Drug Delivery Rev 2005, 57, 2271-2286.

16 Jaszberenyi, Z.; Moriggi, L.; Schmidt, P.; Weidensteiner, C.; Kneuer, R.; Merbach, A. E.; Helm, L.; Toth, E. J Biol Inorg Chem 2007, 12, 406-420. 
17 Aime, S.; Botta, M.; Crich, S. G.; Giovenzana, G.; Palmisano, G.; Sisti, M. Bioconjugate Chem 1999, 10, 192-199.

18 Lou, X.; Zhang, G.; Herrera, I.; Kinach, R.; Ornatsky, O.; Baranov, V.; Nitz, M.; Winnik, M. A. Angew Chem Int Ed 2007, 46, 1-5.

19 Grogna, M.; Cloots, R.; Luxen, A.; Jérôme, C.; Passirani, C.; Lautram, N.; Desreux, J. F.; Detrembleur, C. Polym Chem 2010, $1,1485-1490$.

20 Karfeld-Sulzer, L. S.; Waters, E. A.; Davis, N. E.; Meade, T. J.; Barron, A. E. Biomacromolecules 2010, 11, 1429-1436.

21 Shokeen, M.; Pressly, E. D.; Hagooly, A.; Zheleznyak, A.; Ramos, N.; Fiamengo, A. L.; Welch, M. J.; Hawker, C. J.; Anderson, C. J. ACS Nano 2011, 5, 738-747.

22 Lai, J. T.; Filla, D.; Shea, R. Macromolecules 2002, 35, 6754-6756.
23 Aqil, A.; Vasseur, S.; Duguet, E.; Passirani, C.; Benoit, J. P.; Roch, A.; Muller, R.; Jerome, R.; Jerome, C. Eur Polym J 2008, 44, 3191-3199.

24 Vonarbourg, A.; Passirani, C.; Saulnier, P.; Simard, P.; Leroux, J. C.; Benoit, J. P. J Biomed Mater Res Part A 2006, 78A, 620-628.

25 Passirani, C.; Barratt, G.; Devissaguet, J.-P.; Labarre, D. Life Sci 1998, 62, 775-785.

26 Caravan, P. Chem Soc Rev 2006, 35, 512-523.

27 Perez-Baena, I.; Loinaz, I.; Padro, D.; Garcia, I.; Grande, H. J.; Odriozola, I. J Mater Chem 2010, 20, 6916-6922.

28 Dong, Q.; Hurst, D. R.; Weinmann, H. J.; Chenevert, T. L.; Londy, F. J.; Prince, M. R. Invest Radiol 1998, 33, 699-708.

29 Schmitt-Willich, H. Br J Radiol 2007, 80, 581-582; author reply 584-585. 